\title{
KONSEP DASAR AUDIT SISTEM INFORMASI
}

Dika saputra

165100045

Fakultas Komputer

Dikakotek12@gmail.com

\begin{abstract}
Auditing adalah sebuah prosessistematis secara objektif mendapatkan dan mengevaluasi bukti mengenai pernyataan perihal transaksi dan ekonomi untuk memastikan tingkat kesesuaian antara pernyataan tersebut dengan criteria yang telah di tetapkan.
\end{abstract}

Tanggung jawab audit internal

1. Melakukan tinjauan atas keadaan dan integritas operasi dan keuangan serta bagaimana hal tersebut di identifikasi dan di laporkan

2. Menetapkan apakah system telah di desain sesuai dengan kebijakan operational dan pelaporan perancanaan prosedur hokum yang berlaku

3. Melakukan tinjauan mengenai bagaimana asset dijaga dan memferivikasi asset tersebut

4. Melakukan tinjauan atas operational dan program perusahaan untuk menetapkan apakah mereka telah di laksanakan sesuai rencana

Kata Kunci : audit system informasi

A. PENDAHULUAN

Salah satu bidang yang sangat

pesat kemajuannya adalah
Informasi Technology (IT) atau Information System (IS). Berkembangnya IS membawa 
dampak yang cukup signifikan bagi setiap perusahaan

\section{B. PEMBAHASAN / STUDI KASUS}

Implementasi system informasi dilakukan untuk menunjang aktifitas proses bibnis tersebut. Hal yang sama dilakukan oleh PT.Aneka Solusi Teknologi yang didirikan pada tahun 2004, adalah perusahaan penyedia jasa perbaikan kualitas serta penyelesaian masalah yang terjadi pada elektronik, computer dan mobile phone dengan cukupan layanan nasional. Objek penelitian meliputi bagian penjualan, pembelian dan gudang.

\section{ID SECURITY}

QWTD4452377-ASP-5244107

\section{KESIMPULAN}

Audit dilakukan untuk analisis dan mengetahui keamanan dan integritas data dari system informasi yang digunakan, karena domain ini mencakup pengelolaan kelancaran dan keamanan sistem serta pengelolaan data dan operasional fasilitas.

\section{E. DISKUSI}

Saya bersama teman saya bernama Ahmad Yudi mendiskusikan tentang tahaptahap audit sistem informasi Hasil diskusi dari materi ini adalah Perangkat lunak yang digunakan oleh perusahaan adalah M-Care Sitem dan ESA Sistem. Audit dilakukan untuk analisis dan mengetahui keamanan dan integritas data dari system informasi yang digunakan. Audit menggunakan framework COBIT 4.1 . Domain yang digunakan adalah Delivery Support (DS), karena domain ini mencakup pengelolaan kelancaran dan keamanan system serta pengelolaan data dan operasional fasilitas.

\section{F. REFERENCE}

O. M. Febriani and A. S. Putra, "Sistem Informasi Monitoring Inventori Barang Pada Balai 
Riset Standardisasi Industri Bandar Lampung," J. Inform., vol. 13, no. 1, pp. 90-98, 2014.

[2] A. S. Putra, "Paperplain: Execution Fundamental Create Application With Borland Delphi 7.0 University Of Mitra Indonesia," 2018.

[3] A. S. Putra, "2018 Artikel Struktur Data, Audit Dan Jaringan Komputer," 2018.

[4] A. S. Putra, "ALIAS MANAGER USED IN DATABASE DESKTOP STUDI CASE DB DEMOS."

[5] A. S. Putra, "COMPREHENSIVE SET OF PROFESSIONAL FOR DISTRIBUTE COMPUTING."

[6] A. S. Putra, "DATA ORIENTED RECOGNITION IN BORLAND DELPHI 7.0."

[7] A. S. Putra, "EMBARCADERO DELPHI XE 2 IN GPUPOWERED FIREMONKEY APPLICATION."

[8] A. S. Putra, "HAK ATAS KEKAYAAN INTELEKTUAL DALAM DUNIA TEKNOLOGY BERBASIS REVOLUSI INDUSTRI 4.0."

[9] A. S. Putra, "IMPLEMENTASI PERATURAN

PERUNDANGAN UU. NO 31

TAHUN 2000 TENTANG DESAIN INDUSTRI BERBASIS INFORMATION TECHNOLOGY."

[10] A. S. Putra, "IMPLEMENTATION OF PARADOX DBASE."
PHONE."

A. S. Putra, "IMPLEMENTATION

PATENT FOR APPLICATION WEB BASED CASE STUDI WWW. PUBLIKLAMPUNG. COM."

[13] A. S. Putra, "IMPLEMENTATION SYSTEM FIRST TO INVENT IN DIGITALLY INDUSTRY."

[14] A. S. Putra, "MANUAL REPORT \& INTEGRATED DEVELOPMENT

ENVIRONMENT BORLAND DELPHI 7.0."

[15] A. S. Putra, "PATENT AS RELEVAN SUPPORT RESEARCH."

[16] A. S. Putra, "PATENT FOR RESEARCH STUDY CASE OF APPLE. Inc."

[17] A. S. Putra, "PATENT PROTECTION FOR APPLICATION INVENT."

[18] A. S. Putra, "QUICK REPORT IN PROPERTY PROGRAMMING."

[19] A. S. Putra, "REVIEW CIRCUIT LAYOUT COMPONENT

REQUIREMENT ON ASUS NOTEBOOK."

[20] A. S. Putra, "REVIEW TRADEMARK PATENT FOR INDUSTRIAL TECHNOLOGY BASED 4.0."

[21] A. S. Putra, "TOOLBAR COMPONENT PALLETTE IN OBJECT ORIENTED PROGRAMMING."

A. S. Putra, "WORKING DIRECTORY SET FOR PARADOX 7."

[23] A. S. Putra, "ZQUERY 


\section{CONNECTION}

IMPLEMENTED

PROGRAMMING STUDI

CASE PT. BANK BCA Tbk."

[24] A. S. Putra, D. R. Aryanti, and I. Hartati, "Metode SAW (Simple Additive Weighting) sebagai Sistem Pendukung Keputusan Guru Berprestasi (Studi Kasus: SMK Global Surya)," in Prosiding Seminar Nasional Darmajaya, 2018, vol. 1, no. 1, pp. 85-97.

[25] A. S. Putra and O. M. Febriani, "Knowledge Management Online Application in PDAM Lampung Province," in Prosiding International conference on Information Technology and Business (ICITB), 2018, pp. 181-187.

[26] A. S. Putra, O. M. Febriani, and B. Bachry, "Implementasi Genetic Fuzzy System Untuk Mengidentifikasi Hasil Curian Kendaraan Bermotor Di Polda Lampung," SIMADA (Jurnal Sist. Inf. dan Manaj. Basis Data), vol. 1, no. 1, pp. 21-30, 2018.

[27] A. S. Putra, H. Sukri, and K. Zuhri, "Sistem Monitoring Realtime Jaringan Irigasi Desa (JIDES) Dengan Konsep Jaringan Sensor Nirkabel," IJEIS (Indonesian J. Electron. Instrum. Syst., vol. 8, no. 2, pp. 221-232.

[28] D. P. Sari, O. M. Febriani, and A. S. Putra, "Perancangan Sistem Informasi SDM Berprestasi pada SD Global Surya," in Prosiding Seminar Nasional Darmajaya, 2018, vol. 1, no. 1, pp. 289-294. 